\title{
Nostalgia and Philosophy-Consumption or the Hyperreality of "Filipino Philosophy"
}

Aldrin Mathew L. Go

\begin{abstract}
One of the prevailing agenda of philosophical discourse and inquiry in the Philippine academe is to problematize the existence and status of Filipino philosophy. Filipino professors of philosophy have claimed that the existence of Filipino philosophy is already answered and no longer a legitimate subject of debate. However, the "answer" that ultimately puts this question to rest remains ambiguous. My objective in this paper is to provide an account of this ambiguity and to go through the two pathological responses towards the problem of Filipino Philosophy, namely, (1) the nostalgia for an "authentic" Filipino essence and (2) the culture of philosophy-consumption. The paper consists of three sections: (1) a critique of Abulad's diachronic schematization of Filipino philosophy, (2) a critique of Mercado's attempt to salvage the project of indigenization in his short essay Reflections on the Status of Filipino Philosophy, and (3) a critique of the culture of philosophy-consumption through a return to the problems identified by Emerita Quito in The State of Philosophy in the Philippines and an examination of F. P. A. Demeterio III's taxonomy of Filipino philosophy.
\end{abstract}

Keywords: Baudrillard, Filipino Philosophy, nostalgia, philosophyconsumption

\section{The Colonial and The Indigenous}

7 he historic shift in the Philippine philosophic atmosphere brought about by the advent of secularization destabilized the hegemonic predominance of Scholastic philosophy in academic philosophical discourse. In the late $20^{\text {th }}$ Century, contemporary philosophy (continental, analytic, and Eastern) became widely accessible in the Philippinessupported by the abundance of publications by foreign-trained Filipino

(c) 2021 Aldrin Mathew L. Go

https://www.kritike.org/journal/issue 28/go june2021.pdf

ISSN 1908-7330 


\section{NOSTALGIA AND PHILOSOPHY-CONSUMPTION}

academicians explicating and appropriating various philosophical schemas, discourses, theories, and subjects, i.e., phenomenology, existentialism, structuralism, post-structuralism, critical theory, and so on. The secularization of philosophy in the Philippines provided the necessary conditions to breach the false universality of Scholasticism. Negativity, in the form of secularization, created the space for philosophy in the Philippines to not only liberate itself from the ideological grip of Scholastic thought, but also to harness untapped potentials and explore uncharted territories for philosophical thought. But, as I will argue in this paper, the formation of philosophical thought by Filipino scholars remains constrained - stunted by historical trauma. One can easily infer this from the historical accounts by various Filipino scholars of philosophy that the practice of philosophy in the country mimics how we, culturally, have an unsettling sense of alienation when we try to identify with either Indigenous or Western cultures. Thus, it is imperative to briefly reexamine first how the development of "Filipino Philosophy" has been framed.

In his essay "Contemporary Filipino Philosophy,"1 Romualdo Abulad provides a diachronic schema of Filipino Philosophy's evolutionary development, i.e., the infamous four phases of Filipino Philosophy: 1) First Colonial Phase: the hegemony of scholasticism; 2) Second Colonial Phase: the secularization of philosophy; 3) Early Indigenous Phase: the indigenization of philosophy; 4) Late Indigenous Phase: the post-indigenization of philosophy. The evolutionary development of Filipino Philosophy in Abulad's schematization essentially accounts for the paradigmatic shift from the Colonial to the Indigenous. The term "Colonial" here characterizes the period prior to the question of Filipino Philosophy itself. What was then called "philosophy" was not necessarily a creative inquiry concerning philosophical subjects such as: epistemology, metaphysics, ethics, etc. Rather, it was a period of proliferation, profusion, and (re)production of western philosophical systems by Filipino academicians of philosophy. The term "Indigenous" then pertains to the period where the question of Filipino Philosophy is posed by the proponents of indigenization. Similar to the Colonial phase, the Indigenous phase was also a period of saturation, consumption, (re)production of "indigenous" thought obtained through ethnological, anthropological, or sociological means. The consequence of this is the prevalent conflation between culture and philosophy that has led to the canonization of pre-Hispanic cultural beliefs, practices, and dialects/languages said to originate in the Philippines as placeholders of an unarticulated philosophy.

13.

${ }^{1}$ Romualdo Abulad, "Contemporary Filipino Philosophy," in Karunungan, 1 (1988), 1 -

(c) 2021 Aldrin Mathew L. Go

https://www.kritike.org/journal/issue 28/go june2021.pdf

ISSN 1908-7330

(cc) BY-NC-ND 
Despite the popularity of Abulad's account of Filipino Philosophy's opulence, one can already infer that this diachronic schema is pregnant with problems. The problem with Abulad's diachronic schematization of Filipino Philosophy lies in the inherent inconsistency of the schema itself. It makes the mistaken claim that the progression from one phase to another is akin to that of a Hegelian dialectical negation of the negation. As Demeterio rightfully puts it:

The movement from the early indigenous phase to the late indigenous phase is actually not an evolutionary phase but a devolutionary one. By distancing themselves from the early indigenous phase, many Filipino philosophers slid back to the concerns of the second colonial phase, where they took the easy way again of preoccupying themselves with the purposeless expounding of one foreign philosophy after another. The transition from the early indigenization to the beginnings of the late indigenization is a transition motivated by the intellectual boredom resulting from the over-saturation of works on early indigenous philosophy. 2

However, I claim that we should radicalize Demeterio's conjecture and take it a step further. Philosophy in the Philippines has yet to make this radical transition from the Colonial to Indigenous, as the present mode of philosophy-consumption remains structured by the Colonial. It is not that there was a regression or devolution; rather, there was no progression. What appears to us as Indigenous is "indigenous" against the background of the Colonial. ${ }^{3}$ One would then notice that every attempt at conceptualizing the "indigenous" is, by definition, always-already structured by the Colonial. The "original" referent of "Indigenous" Filipino Philosophy is a pure

${ }^{2}$ F. P. A. Demeterio III, "Thought and Socio-Politics: An Account of the Late Twentieth Century of Filipino Philosophy," in F. P. A. Demeterio's Philosophy and Cultural Theory Page (2002), $<$ https://sites.google.com/site/feorillodemeterio/thoughtandsocio-politics $>$.

${ }^{3}$ What strikes me as an interesting anomaly in Abulad's diachronic schema of the development of Filipino Philosophy is that the Colonial precedes the Indigenous. Intuitively, one would say that the Indigenous logically precedes the Colonial; otherwise, the proponents of ethnophilosophy (e.g., Mercado and Timbreza) are then compelled to admit that what they characterize as "Indigenous Filipino Philosophy" is a product of what de facto is (still) mediated by the Colonial. Thus, there was no transition and that what is characterized as the Indigenous takes place within the Colonial. The only phase of "Filipino Philosophy" is the Colonial Phase going on.

(c) 2021 Aldrin Mathew L. Go

https://www.kritike.org/journal/issue 28/go june2021.pdf

ISSN 1908-7330 


\section{NOSTALGIA AND PHILOSOPHY-CONSUMPTION}

simulacrum ${ }^{4}$ produced within the Colonial regime of philosophy in the Philippines as opposed to it being an excavated reservoir of an "authentic" Filipino essence untainted by colonization.

Alfredo Co is justified in claiming that "there was no visible culture that we could call Filipino when the Spaniards came to these scattered islands" 5 and, even if there was, strictly speaking, it is not Filipino. Co alludes to Nick Joaquin's assertion in his book Culture and History ${ }^{6}$ wherein, prior to Spanish colonization, the pre-Hispanic people that resided in the archipelago were not, strictly speaking, Filipino; or, as Co puts it: "before the Spaniards came, we could be anything but Filipino and when the Spaniards left, we could not be anything but Filipino." ${ }^{\prime 7}$ Co writes:

[T]he Spanish discovered these islands at a time when the natives were just emerging as a group of people, beginning to form a distinct organization and worldview, but the development was nipped in the bud... If our country is a Spanish creation, how did philosophy as a formal discourse all start? If the Spanish colonizers did not find a body of literature when they came, it is evident that there could not have been a philosophy before that. For philosophy, just like literature, comes with a corpus of writing. If literature provides the legends and stories that represent a civilization, philosophy provides a distilled reflection of the people of that civilization. If we did not have a corpus of literary and philosophical works before the coming of the Spaniards, then it follows that philosophy could have only evolved after the creation of the country. ${ }^{8}$

The price paid from this passage from the "pre-Hispanic" (or preColonial) to "Filipino" is the foreclosure or the impossibility of returning to some homeostatic unity of essence prior to the disintegrationdeterritorialization of the "original" essence. Every attempt to return to a

${ }^{4}$ See Jean Baudrillard, "The Precession of Simulacra," Simulacra and Simulation, trans. by Sheila Faria Glaser (Michigan: The University of Michigan Press, 1994), 1-42. The elementary definition of the term "simulacrum" for Baudrillard is that it is "a copy without an original," "a copy of a copy," or "a copy of itself."

${ }^{5}$ Alfredo Co, "In the Beginning ... A Petit Personal Historical Narrative of the Beginning of Philosophy in the Philippines," in Across the Philosophical Silk Road Vol. 6: Doing Philosophy in the Philippines and Other Essays (Manila: UST Publishing House, 2009), 29.

${ }^{6}$ See Nick Joaquin, Culture and History (Manila: Anvil Publishing, 2004).

${ }^{7} \mathrm{Co}$, "In the Beginning," 30-31.

${ }^{8}$ Ibid., 29.

(c) 2021 Aldrin Mathew L. Go

https://www.kritike.org/journal/issue 28/go june2021.pdf

ISSN 1908-7330

(c) $)$ BY-NC-ND 
prelapsarian mode of thought is mediated and no longer authentic. Every "return" is a hyperrealization through the semiurgy of Filipino-signs.

One way of illustrating this point is through Albert Camus's essay The Myth of Sisyphus ${ }^{9}$ where he provides a lucid account man's nostalgia for unity and the gap that separates man from the silence of the world. The human condition constitutes the antagonistic relation between man and the universe and the impossibility of any dialectical "synthesis" or reconciliation. The desire for reconciliation that arises from man's "nostalgia for unity" not only disavows the revelation of the absurd, but also commits a philosophically dishonest move, i.e., the domestication of the ontological impasse discovered from the experience of the absurd by positing or conjuring a transcendental guarantor of homeostatic unity (God, Reason, etc.). The absurd, however, is not some intruder or transcendent agency outside the homeostatic totality that intervenes in what is supposedly the harmonious flow of the world; on the contrary, the absurd is an exigency constitutive of the human condition itself, i.e., the moment when the world returns to itself. The revolt against the absurd, as Camus repeatedly emphasizes, is not the denial of the Absurd. Rather, it is an act of defiance that recognizes that the absurd is an ontological feature of the human condition..$^{10}$ The primordial unity before the revelation of the absurd emerges from the nostalgia for unity, that is, through the escape from the essential character of the absurd, i.e., "opposition, laceration, and divorce."11

In Žižekian dialectical parlance, this absurdist logic comes in the form of an absolute recoil12: "the nostalgia itself produced what it is the nostalgia of." Camus's response to the absurd is not to "overcome" (in the sense of leaping through) the absurd, but in a radically Hegelian twist, to radicalize the absurd itself. The absurd retroactively reveals itself as its own solution (what is revolt if not the redoubling of the absurd?). This is precisely what Camus meant by "the hell of the present is his Kingdom at last." 13 What was once the subordinate moment of the human condition (man's alienation from the world) becomes the totalizing moment (the world is meaningless alienated in-itself). ${ }^{14}$ The same thing can be said of Filipino identity. Every attempt to return to some primordial pre-Hispanic roots ultimately fails, as

${ }^{9}$ Albert Camus, "The Myth of Sisyphus," in The Myth of Sisyphus and Other Essays, trans. by Justin O'Brien (New York: Vintage International, 1983).

${ }^{10}$ Albert Camus, "Metaphysical Rebellion," in The Rebel, trans. by Anthony Bower (New York: Vintage International, 1984), 25.

${ }^{11}$ Ibid., 32.

${ }^{12}$ See Slavoj Žižek, Absolute Recoil: Towards A New Foundation of Dialectical Materialism (London: Verso Books, 2014).

${ }^{13}$ Ibid., 52.

${ }_{14}$ Slavoj Žižek, "Is it Still Possible to Be a Hegelian Today?" in Less Than Nothing: Hegel and the Shadow of Dialectical Materialism (London: Verso Books, 2012), 234.

(C) 2021 Aldrin Mathew L. Go

https://www.kritike.org/journal/issue 28/go june2021.pdf

ISSN 1908-7330

(cc) BY-NC-ND 


\section{NOSTALGIA AND PHILOSOPHY-CONSUMPTION}

"the more Filipino philosophy persists in its recovery of a lost identity, the deeper it gets stuck in such a quandary." 15 Thus, the process of "recovering" primordial Filipino roots reveals itself as a simulation of Filipino Philosophy, that is, without an original or "real" referent.

To recapitulate, Abulad's Quito-centric periodization of Filipino philosophy allows us to see where the problem resides. The formation of Filipino Philosophy remains constrained, not by the imperialist influence of western philosophical traditions (as philosophy in the country began precisely through this), but by the inability to accept that Filipino subjectivity is essentially a by-product of colonialization. The paradox is that, while we were forced to fall from paradise, this fall nonetheless introduces a space-a unique opportunity for critical philosophizing and cultural transformation beyond the confines of pre-Colonial culture. However, the problem persists. What impedes us from utilizing this unique opportunity for creative philosophizing, as I will develop further in this paper, is our historical trauma that manifests itself in our nostalgia for an "authentic" Filipino essence and the academic culture of philosophy-consumption.

\section{The Nostalgia for an "Authentic" Filipino Essence}

When the real is no longer what it was, nostalgia assumes its full meaning. There is a plethora of myths and origin and of signs of reality - a plethora of truth, secondary objectivity, and authenticity. ${ }^{16}$ - Jean Baudrillard, Simulacra and Simulation

Leonardo Mercado, in an effort to salvage the fruits of the project of indigenization, vehemently rejects Co's contention that the absence of "indigenous" philosophical writing ultimately renders "Filipino Philosophy," prior to colonization, non-existent. Mercado uses the writing down of Australian aborigine language as an example to illustrate his point; he writes:

A part of culture is the ideational, which includes concepts and values; this is the area of philosophy. Now, if somebody [Alfredo Co] will object: "If there is no written philosophy or text, then that group has no philosophy." The objection may be applied to language. If there is no written grammar, then there is no language.

${ }^{15}$ Jovito V. Cariño, "Re-thinking Filipino Philosophy with Gilles Deleuze," in Mabini Review, 2 (2013), 67.

${ }^{16}$ Baudrillard, "Precession of Simulacra," 6-7.

(c) 2021 Aldrin Mathew L. Go

https://www.kritike.org/journal/issue 28/go june2021.pdf

ISSN 1908-7330

(c) $)$ BY-NC-ND 
But the members of the tribe perfectly speak their language even if there is no written grammar. ${ }^{17}$

Mercado then argues that, an example of "an unwritten language being written" is homologous to the project of indigenization, which is a case of an unwritten philosophy being written"; he continues:

The grammar has to be observed and written down by a language scholar. Australian national television reported that the language of a group of Australian aborigines is about to vanish because the few members are dying out. So, a Caucasian anthropologist spent his time with them, learned their language, and wrote down its grammar. When applied to worldview or philosophy, here is an example of an unwritten grammar being written. ${ }^{18}$

At first glance, one might immediately be convinced that Mercado's example provides and justifies the project of indigenization that the absence of textual evidence does not necessarily mean the non-existence of Filipino Philosophy. The unwritten-ness of Filipino Philosophy is contingent to it being simply being unwritten. The problem with this argument becomes evident when one locates what exactly holds this argument together. Mercado's approach to Filipino Philosophy as "the writing down of an unwritten philosophy" is already mediated by western theoretical apparatuses. ${ }^{19}$

${ }^{17}$ Leonardo Mercado, "Reflections on the Status of Filipino Philosophy," in Kritike, 10 (2016), 25.

${ }^{18} \mathrm{Ibid}$. One of the possible refutations against this argument would be for Mercado to qualify his example by providing further specifications and say that: "To clarify, the unwritten grammar of Australian aborigines is simply unwritten by them. This is to say that they already have a written counterpart of the unwritten words. However, the problem at hand is that they simply did not bother to write it down." But of course, if this were true, why then, in order to save the existence of the unwritten grammar of aborigines, did the anthropologist need to intervene and learn their language in order to save it? If such a grammar is self-constituted and complete in-itself, then he anthropologist's intervention would be a mere documentation and not an example of "an unwritten language being written."

19 See Leonardo Mercado, "Language, Culture, and Thought," Elements of Filipino Philosophy (Tacloban: Divine Word University Press, 1976), 16-46. See also Mercado, "Reflections on the Status of Filipino Philosophy," 21-28; Leonard Mercado, Essays on Filipino Philosophy (Manila: Logos Publication, 2005). A simple browse through his work would reveal that he is unconsciously not faithful to his own objective of "Indigenous Filipino Philosophy" as he constantly relies on and references Merleau-Ponty, Wittgenstein, Heidegger, and others. Even the idea that language is intimately related to or being a placeholder of thought is a western idea. 


\section{NOSTALGIA AND PHILOSOPHY-CONSUMPTION}

While at the level of empirical fact, the "unwritten grammar being written" does "legitimize" itself in the prospect of it being written, but one must take into account the intervention of the anthropologist. Before the aborigine language was written down by the anthropologist, the aborigine language was not simply unwritten, but its unwritten-ness is constitutive of that language's identity. The irony of writing down the unwritten aborigine language is that the very act of writing down the unwritten language deaboriginizes it. Mercado's anthropological study in his book Elements of Filipino Philosophy makes the self-sabotaging gesture in his attempt to derive or write down an unwritten philosophy through his meta-linguistic analysis of some indigenous languages in the Philippines (namely: Tagalog, Ilokano, and Bisaya). Pada makes the right assessment when he says that "there is a certain sense of ambiguity when Mercado tries to assert that the tools and methods in evaluating Filipino philosophy ought to be done in a non-Western category." ${ }^{20}$ What Mercado fails to see in his analysis is his own shadow (i.e., the historical horizon where his work is situated) in his anthropological study. ${ }^{21}$ Abulad's schema makes this evident.

A peculiar detail in Abulad's periodization is that it begins with the "Colonial" before the "Indigenous" and not the other way around. This is to say that, prior to the anthropological meta-linguistic investigations done by the proponents of indigenization, there is, strictly speaking, no Indigenous Filipino Philosophy. One can then refer to Baudrillard's critique of ethnology: "for ethnology to live, its object must die" $^{22}$-for indigenous Filipino Philosophy to live, its object must die. The project of indigenization merely confirms the death of its object (i.e., the "original" referent). In other words, the only "phase" of "Filipino Philosophy" is the colonial phase going on: the phase of profusion and proliferation of Filipino-signs.

Despite these criticisms, one can still say that the anthropological or ethnophilosophical studies of Mercado remain valuable as it was able to

However, one could defend him by arguing that his objective is "nationalist" as opposed to "nativist."

${ }^{20}$ Roland Theuas Pada, "The Methodological Problems of Filipino Philosophy," in Kritike, 8 (2014), 31.

${ }^{21}$ It would be more plausible if Mercado would instead say that what he has been trying to do is to construct a philosophy based on native sources, as opposed to the futile project of accounting for or being the "objective spokesperson" of "the philosophy of the Filipino people." In other words, he could defend his work by simply saying that his project is an attempt to formulate his philosophy-a philosophy inspired by "elements" harvested through metalinguistic analysis of Philippine dialects/languages.

${ }^{22}$ Baudrillard, "Precession of Simulacra," 7. The same criticism was already made by Emerita Quito in her monograph The State of Philosophy in the Philippines where she writes: "[Mercado's] attempts are laudable in the sense that he at least wants to establish the Filipino identity. On the other hand, his work is reputed to be stilted and contrived, the contention being that he artificially made up a "Filipino Philosophy" out of mere linguistic ideas.

(c) 2021 Aldrin Mathew L. Go

https://www.kritike.org/journal/issue 28/go june2021.pdf

ISSN 1908-7330

(cc) BY-NC-ND 
provide an account of Filipino's phenomenological experience in their use of language. But, with regard to the formation of Filipino Philosophy, the project of indigenization is passé-a historical deadlock. The deadlock of indigenization is precisely because of the impossibility of resurrecting an original referent through the necromancy of meta-linguistic theorization of dialects and languages. What indigenization can hope to conjure from this is nothing more than a pure simulacrum of itself. The concatenation of Filipinosigns. The futility of the indigenization, ironically, becomes much clearer in Batoon's defense of Mercado.

Emmanuel Batoon defended Mercado's achievements on the basis that, in the first place, it is impossible to provide a categorical answer to what Filipino Philosophy is. Mercado, Batoon says, "is not the creator of Filipino philosophy - the Filipino people are" 23 and it is for this precise reason that the limit of the project of indigenization is no other than itself. One can see this by simply pushing Batoon's contention to the end; rendering the nihilistic arrogance in it apparent. Batoon makes an obvious contradiction when he says that "Co is unjustified when he accused Mercado of failing to come up with a 'categorical' conclusion regarding the 'essential' Filipino philosophy. Mercado did not do this precisely because he cannot do it; he is not the creator of Filipino philosophy - the Filipino are."24 Then, exactly after he says this, Batoon continues: "Even the Filipino people cannot create a categorical 'essential' Filipino philosophy because it is an artificial cultural symbolic system, not a natural phenomenon that changes through time and space by way of cultural acculturation like assimilation and amalgamation." ${ }^{25}$ In saying that neither Mercado nor the Filipino people are able to create and categorically assert a Filipino philosophy, at what point then does a certain philosophical discourse identify itself as a determinate philosophy? The inevitable consequence of this is to say that that Filipino philosophy does not, in any meaningful way, exist, i.e., "Filipino philosophy" can never become a determinate philosophy-a philosophy that participates as a contending discourse in the universal discourse of philosophy.

Philosophers working from other countries such as: France, Germany, the United Kingdom, the United States, China, India, Japan, etc. do not have this absurd criterion for their philosophizing to be "authentic." We can even go as far as to say that philosophy has no obligation to conform, mirror, appropriate, or translate into "philosophy" the predominant culture of a given ethnicity to gain the stamp of authenticity, as philosophy intervenes more than it conforms or regurgitates cultural signs and converts it into a

\footnotetext{
${ }^{23}$ Emmanuel Batoon, “Tracing Mercado's Anthropological Perspective (Second of Two Parts)," in Kritike, 8 (2014), 4.

${ }^{24}$ Ibid.

${ }^{25} \mathrm{Ibid}$.
}

(c) 2021 Aldrin Mathew L. Go https://www.kritike.org/journal/issue 28/go june2021.pdf ISSN 1908-7330 


\section{NOSTALGIA AND PHILOSOPHY-CONSUMPTION}

philosophy. Philosophy never simply reiterates, articulates, or enumerates "Filipino" traits but also undermines what is reiterated, articulated, or enumerated. ${ }^{26}$ The problem with taking philosophy as being a set of opinions, beliefs, or the collective Weltanschauung of a given ethnicity is that it renders such a philosophy indistinguishable from anthropology, sociology, or ethnology. Philosophical inquiry extends beyond the mere documentation or description of a given ethnicity's collective belief, as the scope of philosophy is always universal. The goal of philosophy is to satiate man's inherent desire to $\mathrm{know}^{27}$ even when it means absolutely rejecting the culture of one's ethnicity.

Philosophy is therefore not the collective belief of the people. To be clear, the criticism made against Mercado (or indigenization in general) here is not that his entire project was futile in-itself. Rather, the task itself of "writing an unwritten philosophy" from the standpoint of some objective observer, spokesperson, or transmitter of some prelapsarian essence, idea, or referent of the "Filipino" is not only problematic but also an impossible task. The implicit mythological presupposition posited by proponents of indigenization is that pre-Colonial/Hispanic culture is a unified undifferentiated One, i.e., without antagonisms, contradictions, or difference (in the Deleuzian sense). But, as mentioned above, it is the nostalgia itself that creates that from which it is the nostalgia of. What is pursued by indigenization is a pure simulacrum of the "Filipino" (in the same way as what decaffeinated coffee is to coffee). If the "Filipino" was a product of colonization, indigenization offers to us a "de-colonized" Filipino that allows us to enjoy our cake (the Filipino) and eat it too (i.e., without the baggage of colonization). What we get is a "Filipino" that is more Filipino than Filipinoa hyperreal "Filipino" that does not refer to any "real." Here, we get the precedence of the simulacral Filipino over "real" Filipino. And to push this point further, Baudrillard will go as far as to say the "real" is a product of simulation, i.e., even the "real" is nothing but a simulacrum. In other words, we are always-already entangled within an imbroglio of signs. The referent

${ }^{26}$ One can even say that iteration is never simply a mere iteration. Even the legitimization of a certain culture is already a form of intervening, as iteration of this kind is not simply the repetition of the Same; rather, it is a repetition that produces something radically different in what is repeated. This, I think, is the point Gilles Deleuze tries to make in Difference and Repetition wherein repetition is not synonymous to an identical replication. What repetition repeats is the virtual, the intensities, the untapped possibilities of what is repeated. See Gilles Deleuze, Difference and Repetition, trans. by Paul Patton (Columbia: Columbia University Press, 1994).

${ }^{27}$ Immanuel Kant, "Preface to the First Edition," Critique of Pure Reason, trans. by J. M. D. Meiklejohn (London: Everyman's Library, 1993), 4.

(c) 2021 Aldrin Mathew L. Go

https://www.kritike.org/journal/issue 28/go june2021.pdf

ISSN 1908-7330

(c) $)$ BY-NC-ND 
of the sign is nothing more than the surface "depth effect" produced the sign itself. 28

The fundamental flaw of the project of indigenization is not due to a mere methodological problem, as any method motivated by nostalgia would inevitably lead to the same problem. Baudrillard's theorization of hyperreality, simulation, and referentiality provides an interesting account of why any "critical" thought that is motivated by nostalgia would always lead to a failed return of the original. The "return" to an "original" referent is already a (re)production. As Baudrillard writes:

The very definition of the real is that which it is possible to provide an equivalent reproduction. It is a contemporary of science, which postulates that a process can be reproduced exactly within given conditions, with an industrial rationality which postulates a universal system of equivalences (classical representation is not equivalence but transcription, interpretation and commentary). At the end of this process of reproducibility, the real is not only that which can be

28 Another way of understanding this point is through Baudrillard's critique of Benveniste in his "early" work. i.e., Jean Baudrillard, For a Critique of the Political Economy of the Sign, trans. by Charles Levin (New York: Verso Books, 2019). In Problems in General Linguistics, Benveniste sought to provide an account for the internal necessity of the Sign, i.e., the necessary relation between Signifier and Signified (as opposed to Ferdinand de Saussure's account of signs as arbitrary and contingent) by transposing arbitrariness or contingency from within the Sign into the relation between the Sign and the Referent.

The consequence of this is that it lays bare what actually takes place in the process of signification takes place. Baudrillard's critique of Benveniste is that his idealist solution to the arbitrariness of the sign does not work. It merely attempts to displace the problem, yet it only ends up turning back unto itself. For Baudrillard, there is no real distinction between the Sign and the Referent. The arbitrary relation between the Sign and the Referent is precisely due to the arbitrariness of the sign itself. As Baudrillard writes: "There is no distinction between the sign and the phenomenal referent, except from the metaphysical perspective that simultaneously idealizes and abstracts the sign and the Lebenswelt, the one as form, the other as content, in their formal opposition. Having provided itself with false distinctions, it cannot be expected to resolve them except with false concepts. But such distinctions are strategic and operational-that is the point. To resolve them (and to rupture the conceptual unreality, which would be the only means of resolving the false problem of the arbitrariness and motivation of the sign) would amount to shattering the possibility of all semiology" [Baudrillard, For a Critique of the Political Economy of the Sign, 158]. What this entails is that there is no "reality" prior to signification. It is the process of signification that produces the distinction between the Sign and the Referent; or, properly speaking, the distinction between the Signifier and the Signified-Referent (the gap immanent to the sign itself). The Signified-Referent serves as the fragile "substance" or reality principle that constitutes the sign's rationality. The "real" that "the sign 'evokes' (the better to distance itself from it) is nothing but the effect of the sign, the shadow that it carries about, its "pantographic" extension" [Ibid., 156]. See Ibid., 145-169.

(c) 2021 Aldrin Mathew L. Go

https://www.kritike.org/journal/issue 28/go june2021.pdf

ISSN 1908-7330 


\section{NOSTALGIA AND PHILOSOPHY-CONSUMPTION}

reproduced, but that which is always already reproduced: the hyperreal. ${ }^{29}$

Thus, the task of Filipino academicians of philosophy today is to take the risk of establishing a categorical position on philosophical problems or subject-matters; and, in the very participation into the discourse of philosophy does one retroactively determine what Filipino philosophy is. One should radically oppose the constant self-probing of whether one's philosophical work is Filipino. The goal should be the exact opposite. The question ought to be asked is whether our discourse enters the universal discourse of philosophy. Slavoj Žižek, in a conversation with Glyn Daly, makes a wonderful point about philosophy and how philosophers should take the risk to make categorical assertions:

I believe in clear-cut positions. I think that the most arrogant position is this apparent, multidisciplinary modesty of "what I'm saying now is not unconditional, it is just a hypothesis," and so on. It is really the most arrogant position. I think the only way to be honest and to expose yourself to criticism is to state clearly and dogmatically where you are. You must take the risk and have a position. ${ }^{30}$

In other words, we cannot to assume a transsubjective meta-position outside the continuum of local cultures and "objectively" observe the totality of particular identities' opinions, beliefs, or weltanschauung to derive an "objective" account of Filipino philosophy. Such a position is impossible to assume. One should instead risk a particular position in the universal discourse of philosophy-a position that can be (albeit not necessary) radically opposed or antithetical to the normative beliefs of one's culture or ethnicity. As I have categorically asserted and established above, Filipino identity is essentially a product of colonization. Filipino academicians should resist preferring "indigenous" influences by virtue of it being indigenous. The veracity or discursive power of a certain philosophical work is not measured by the fidelity of that philosophical work to the native ideas of the ethnicity from where the author of such work belongs. Rather, it is measured against other philosophical works that approach a universal philosophical subject in

\footnotetext{
${ }^{29}$ Jean Baudrillard, "The Order of Simulacra," in Symbolic Exchange and Death, trans. by Iain Hamilton Grant (London: SAGE Publishing, 1993), 73; It is important to note that this point does not apply only to referents irretrievably lost in time, but also to any referent in general.

30 Slavoj Žižek and Glyn Daly, "Contexts and Horizons: Opening the Space for Philosophy," in Conversations with Žižek (United Kingdom: Polity Press, 2004), 45.
}

(C) 2021 Aldrin Mathew L. Go

https://www.kritike.org/journal/issue 28/go june2021.pdf

ISSN 1908-7330

(cc) BY-NC-ND 
which the philosophical work is an answer to or a critique of. As Žižek repeatedly quotes from Hegel's Phenomenology of Spirit: "[T]he life of Spirit is not the life that shrinks from death and keeps itself untouched by devastation, but the life that endures it and maintains itself in it. It wins its truth only when, in utter dismemberment, it finds itself." 31 In the same way, we should take the present as an opportunity for radical creativity and to liberate philosophical thinking from its self-imposed shackles.

\section{The Culture of Philosophy-Consumption}

The culture of philosophy, according to various schematizations and taxonomic accounts given by Filipino scholars, remains confined within the vicious cycle of profusion, proliferation, production, and appropriation of "philosophy-commodities" manufactured from foreign academic factories. I would like to call this cultural phenomenon in the academe: philosophyconsumption. Despite the predominant anti-intellectualist aversion to what is derogatorily called "armchair philosophizing," we have yet to actually philosophize in a radically theoretical manner; on the contrary, the trend is the exact opposite. ${ }^{32}$ The relationship of Filipino scholars to philosophy remains to be that of consumption: the purposeless exposition of foreign systems or the vulgar application or instrumentalization of philosophical systems to the Philippine context characterizes the poverty of philosophy in the country. The complacence of some Filipino scholars to put to rest the question of Filipino philosophy demands a brutal clarificatory question, namely: What exactly was the answer that has ultimately put the question of Filipino philosophy's existence to rest?

Before approaching this question, it is necessary to point out an important distinction between "Philosophy in the Philippines" and "Filipino Philosophy." The former pertains to the presence of philosophy in the country (which is undeniable) while the latter pertains to, quite literally, the philosophies of/by Filipinos (i.e., a testament of the country's productivity in philosophy). The purpose of making this distinction is to avoid the (false) conclusion that the presence of philosophy in the country answers the question of Filipino philosophy's existence. The relevance of this point will become evident as we examine the schemas or taxonomies constructed by

${ }^{31}$ G. W. F. Hegel, "Preface," in Hegel's Phenomenology of Spirit, trans. by A. V. Miller (Oxford: Oxford University Press, 1977), 19.

${ }^{32}$ See F. P. A. Demeterio III, "Status of and Directions for 'Filipino Philosophy' in Zialcita,

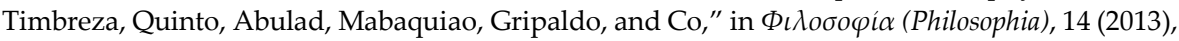
186-215. See also F. P. A. Demeterio III, "Assessing the Development Potentials of Some Twelve Discourses of Filipino Philosophy," in Philippiniana Sacra, 49 (2014), 189-230.

(c) 2021 Aldrin Mathew L. Go

https://www.kritike.org/journal/issue 28/go june2021.pdf

ISSN 1908-7330

(cc) BY-NC-ND 


\section{NOSTALGIA AND PHILOSOPHY-CONSUMPTION}

some Filipino scholars with regard to the publications done by their predecessors and contemporaries.

One can ask a naïve question about Emerita Quito's monograph The State of Philosophy in the Philippines33: why was is not titled "The State of Filipino Philosophy"? The obvious reason is that the subject of her monograph was the social, political, economic, and cultural conditions of philosophy in the country (at the time) as well as the structural and institutional limitations that constrain its development. However, one would notice that the implicit thesis of her monograph is that, despite the various publications (during her time and perhaps even now) and the efforts of the project of indigenization, philosophy in the Philippines nonetheless remains in the state of poverty. Demeterio, in his rereading ${ }^{34}$ and critical reflection of his rereading 35 of Emerita Quito's monograph, provides an elaborate description and contextualization of Quito's diagnosis of Filipino philosophy's underdevelopment. Demeterio re-organized Quito's diagnosis under four headings: (1) The Historical Problem; (2) The Economic and Institutional Problems; (3) The Linguistic Problems; (4) The Cultural Problem. I will briefly go over these problems to later highlight that the primary problem preventing Filipino philosophers from developing philosophy are not the ones identified by Quito (as I will argue later that these are merely secondary problems). Rather, the primary problem is the culture of philosophyconsumption.

The historical problem concerns the hegemony of Thomistic ideology in philosophy and the Marcos dictatorship. During the early phase of philosophy in the country (pre-Quito), Filipino academicians championed Thomistic philosophy and taught it with indisputable authority. But despite this, Thomistic ideology continues to plague philosophy (and perhaps plagues even Thomistic philosophy itself). ${ }^{36}$ The early period of philosophy was a period of mere profusion, proliferation, saturation of Thomistic ideas. The lack of creative or innovative philosophizing that characterized this period is precisely due to the false equivalence between philosophy and Thomism. You get the hyperreal scenario of an absolutely homogenized and totalized discourse of philosophy that has foreclosed the possibility of

\footnotetext{
${ }^{33}$ Emerita Quito, The State of Philosophy in the Philippines (Manila: De La Salle University, 1983).

${ }^{34}$ F. P. A. Demeterio III, "Re-reading Emerita Quito's Thoughts Concerning the Underdevelopment of Filipino Philosophy," in Diwatao, 1 (2001).

${ }^{35}$ F. P. A. Demeterio III, “A Critical Reflection on My Reading and Re-Reading of Emerita Quito's Thoughts on the Underdevelopment and Hope for the Development of Filipino Philosophy," in Фı৯обофía (Philosophia), 21 (2020), 169-186.

${ }^{36} \mathrm{Ibid} ., 175$. "We are overly concerned with the exactness of our interpretations and avoiding distorting such philosophical trends...that left no room for creativity and experimentation."

(c) 2021 Aldrin Mathew L. Go

https://www.kritike.org/journal/issue 28/go june2021.pdf

ISSN 1908-7330
}

$(\mathrm{Cc}) \mathbf{B Y - N C - N D}$ 
reversibility. ${ }^{37}$ The paradox is that there is philosophy (in the naïve sense that Thomism is a philosophy), but at the same time there is none (the absence of creative philosophizing). One can already see here why the distinction I pointed out earlier between "Philosophy in the Philippines" and "Filipino Philosophy" is important. The presence of philosophy in the country does not presuppose that Filipino philosophy exists.

The economic and institutional problem concerns the lack of funding to support the formation of Filipino philosophy. In our contemporary neoliberal capitalist society, this concern is self-explanatory as philosophy is not exactly a vocation in which its professionals contribute directly to the market or economy. However, according to Demeterio, this is no longer a problem today as academic institutions already offer research grants and scholarships for scholars who would like to pursue a career in philosophy. The problem is that, in solving this problem, the economic and institutional problem reveals itself as a secondary problem. The ambiguity of the "answer" to the question of Filipino philosophy still remains.

The linguistic problem concerns the lack of proficiency with European languages like German and French and the need to recover our native tongue. Demeterio was right to emphasize that studying foreign languages should only be done if the research agenda requires it. Proficiency in foreign language is not a prerequisite in the formation of Filipino philosophy. It merely complements it. However, I disagree on his second point that "the real spirit and experiences of a people can only be expressed fully by the native tongue." 38 The capacity in fully expressing one's thoughts is not guaranteed by the appeal to the vernacular. Nothing prevents us from also saying that our predicament comes precisely from this nostalgia for, appeal to, and reification of the vernacular. The linguistic problem reveals itself as a trivial problem. Even if we solve this problem, it would only mean that we are proficient in specific or various languages or that we write in Tagalog (or any other local language). There is no necessary relation between proficiency in some European languages or the use of the vernacular with the formation or development of a homegrown philosophy. In other words, even if we hypothetically suppose that everyone in the Philippines is proficient in French, German, English, Tagalog, etc., still, this does not necessarily mean

${ }^{37}$ Baudrillard's notion of reversibility pertains to the resistance to operationality, finality, circulation, or the expurgation of radical alterity under the auspices of the Code or the System. Baudrillard's theorization of simulation should not be construed as an attempt to return to a time prior to simulation nor an attempt to get rid of simulation, but as an attempt for thought to catch up to the simulation/reality. For Baudrillard's discussion of reversibility, see Jean Baudrillard, Fatal Strategies, trans. by Phil Beitchman and W. G. J. Niesluchowski (Los Angeles: Semiotext(e), 2008).

${ }^{38}$ Demeterio, "Re-reading Emerita Quito's Thoughts."

(c) 2021 Aldrin Mathew L. Go

https://www.kritike.org/journal/issue 28/go june2021.pdf

ISSN 1908-7330

(cc) BY-NC-ND 


\section{NOSTALGIA AND PHILOSOPHY-CONSUMPTION}

that a Filipino philosophy will emerge from it. Philosophy does not derive its foundation from the language proficiency of the philosopher.

The cultural problem pertains to Quito's observation that philosophical thinking is generally dismissed by Filipinos themselves, as the word pilosopo (philosopher) is often used as "a pejorative name for anyone who argues lengthily, whether rightly or wrongly." 39 Given the predominant anti-intellectual culture in the country, one of the major obstacles in the formation of Filipino philosophy is the Filipino itself. When compared to western countries who (relatively) value philosophy and philosophers, Filipinos dismiss philosophical thinking as verbose charlatanism. The advent of philosophy, despite its relatively long history in the Philippines, is still way ahead of its time. The untimely arrival of philosophy has made the Filipino radically impotent in its wake. In other words, the general attitude of Filipino public is not yet ripe for philosophy and for the flourishing of philosophical thought. Filipinos remain confined in their preference for reductive simplification of complex realities and their aversion to nuanced interrogation and articulation of philosophical subjects. The objection I have of Quito and Demeterio's assessment, however, is that, while I absolutely agree that the problem is indeed cultural, the problem of Filipino philosophy's formation is not that the general Filipino public's attitude towards philosophy is negative. The problem of Filipino philosophy's underdevelopment is elsewhere.

At the risk of offending our predecessors, I claim that the cultural problem of Filipino philosophy's underdevelopment is not due to how the general Filipino public perceives philosophy. Rather, the problem is due to how Filipino scholars of philosophy approach, relate, and engage in philosophy. As mentioned above, the culture of philosophy-consumption is characterized by the purposeless explication of foreign philosophical systems and the vulgar appropriation or instrumentalization of philosophical systems in the name of relevance. One way to illustrate this phenomenon is to begin by reformulating Abulad's schema in terms of shifting trends in philosophyconsumption:

1. First Colonial Trend - The consumption of Scholastic philosophy-sign

2. Second Colonial Trend - The consumption of (secular) foreign philosophy-signs

${ }^{39}$ Quito, The State of Philosophy in the Philippines, 10.

(c) 2021 Aldrin Mathew L. Go

https://www.kritike.org/journal/issue 28/go june2021.pdf

ISSN 1908-7330

(c) BY-NC-ND 
3. Early "Indigenous" Trend - The consumption of indigenous Filipino philosophy-signs

4. Late "Indigenous" Trend - The return to the consumption of foreign philosophy-signs

In this reformulation of Abulad's schema, it is easier now to see why there was no progression in "Filipino philosophy." The change is nothing more than a shifting of trends in philosophy-consumption. I would even go as far as to extend the same criticism to other taxonomies and schemas, namely those by: Zialcita, Timbreza, Quito, Mabaquiao, Gripaldo, Co, and Demeterio. What are their taxonomies, schemas, or periodization if not an account of philosophy-consumption (as opposed to "Filipino philosophy")? The question worth raising at this point is a simple and naïve one: What did they mean exactly by "Filipino philosophy" in the taxonomies, schemas, or periodizations?

Demeterio's essay Assessing the Development Potentials of Some Twelve Discourses provides an elaborate account and synthesis of the schemas, taxonomies, and periodizations made by his predecessors. One can infer from Demeterio's (synchronic) quasi-prescriptive taxonomy that it not only accounts for the potentials of "Filipino philosophy," but also Filipino philosophy's polymorphous existence. The analysis of discourses and the appraisal of their development potentials can serve as guides that can later inspire Filipino scholars to pursue a specific discourse of Filipino philosophy. But a question worth posing about this taxonomy is: Are these "discourses" discourses of "Filipino philosophy"? Are they not simply discourses that Filipino scholars of philosophy can pursue? The problem with framing the project of developing Filipino philosophy as the pursuit of such and such philosophical discourses is that it solidifies (and perhaps even promotes) the culture of philosophy-consumption (I can write on this discourse; and later that discourse, and so on...). And, as we can infer from the various taxonomies of "Filipino Philosophy," the predominant practice of philosophy in the country is to specialize on a discourse and a philosopher and repeatedly publish papers applying their selected thinker into the sub-discourses of his selected discourse of expertise.

For example, a Filipino scholar of philosophy can specialize on, let us say, Karl Marx, and repeatedly publish works applying Marx to his discourse of specialization or to simply explicate Marx and later call himself a philosopher for doing so. ${ }^{40}$ The consequence of which is that the bar for what

${ }^{40}$ One cannot deny the importance of explicating the complex ideas of a philosopher and applying them to discourses or realities; but it should not necessarily follow from this that one becomes a philosopher by merely explicating or applying a philosopher.

(c) 2021 Aldrin Mathew L. Go https://www.kritike.org/journal/issue 28/go june2021.pdf ISSN 1908-7330 


\section{NOSTALGIA AND PHILOSOPHY-CONSUMPTION}

can be considered as "Filipino Philosophy" is set to an insanely low standard of being a mere explicator and user. One would notice this when we refer to "Filipino Philosophers." When we refer to a Filipino Philosopher almost immediately think of them in terms of the thinker(s) they specialize in and the published works where they have applied their selected thinker on a particular discourse. Compared to renowned foreign philosophers who have spent their philosophical career explaining themselves and challenging the philosophies of their predecessors and contemporaries, the general attitude or standard of Filipino philosophers to what counts as "practicing of philosophy" is explaining other thinkers and applying them in the name of relevance and being a published academic. The problem of philosophyconsumption is precisely this. The treatment of philosophy as a kind of commodity to be consumed instead of something that is perpetually challenged and innovated.

One can now see the relevance of Demeterio's taxonomical essays on Filipino Philosophy, as it clarifies what Filipino scholars of philosophy actually mean when the use the term "Filipino philosophy." The definition is an interesting one: "Filipino philosophy" is the published works of Filipino scholars of philosophy that engages in the discourses of Filipino philosophy," i.e., "Filipino Philosophy as..." In other words, the question of Filipino philosophy for Demeterio and others is passé because published works that deal with the discourses of Filipino philosophy exist. Demeterio makes this point in his concluding remarks in Status and Direction of "Filipino Philosophy" where he asserts that the question of Filipino philosophy ought to be rendered obsolete, as it would be "an insult to the toils of Filipino thinkers who trod the path of philosophizing and sufficiently answered the same question." 41 He writes:

Hence in having rendered obsolete the question "Is there a Filipino philosophy?" Filipino students and younger scholars of philosophy could select which among the twelve highly developmentally useful forms of Filipino philosophy they want to work on. By doing so, their consequent philosophical researches would hopefully contribute to the further enrichment of Filipino philosophy until the question, "Is there a Filipino philosophy?" fades away from the Philippine historical horizon. ${ }^{42}$

${ }^{41}$ Demeterio, "Status of and Directions for 'Filipino Philosophy'," 186.

${ }^{42}$ Ibid., 212.

(c) 2021 Aldrin Mathew L. Go

https://www.kritike.org/journal/issue 28/go june2021.pdf

ISSN 1908-7330

(c) BY-NC-ND 
Abulad, appealing to the indisputable existence of published works, also makes the similar declaration on Filipino philosophy:

[T] here is academic or professional philosophy in the Philippines, backed up yet by some publications, both books and journal articles, which cannot be mistaken for anything other than philosophy, and so I propose that we already happily lay to rest the question as to whether or not there is Filipino philosophy, natural or academic. The question thus left to is only this: How do we do philosophy in the Philippines? ${ }^{43}$

However, a Baudrillardian critique can be made here: But what if the appeal to published works on philosophy merely functions as an alibi in order to repress the non-existence of Filipino philosophy? If Filipino philosophy is defined as "the published works of Filipino scholars of philosophy that engages in the discourses of Filipino philosophy" and the "proof" of its existence is the existence of published works in the country, then we are no different from Mercado when he asserts that Filipino philosophy exists in indigenous cultures, beliefs, and folk-sayings and that the problem is that it is simply unwritten. For the taxonomists of "Filipino philosophy," Filipino philosophy exists in the published works of scholars and the problem is that it is simply underdeveloped. "Filipino philosophy" exists in the promise that there is Filipino philosophy contained in the published works of scholars and we should simply take their word for it.

\section{Concluding Remarks}

To return to the question I posed earlier: What exactly was the "answer" that has ultimately put the question of Filipino philosophy's existence to rest? The answer: the existence of published works by Filipino scholars of philosophy. When foreign philosophers are asked about their philosophy, they refer to their ideas, concepts, theories, and theoretical struggles they face against other theories before they even begin referring to their published works. In the Philippines, we do somewhat the opposite, but worse. Taxonomists refer to the existence of published works and then assume that we already know what "Filipino philosophy" is by virtue of being able to taxonomize it. The taxonomies of so-called "Filipino philosophy" are actually taxonomies of published and future works of

${ }^{43}$ Romualdo Abulad, "Doing Philosophy in the Philippines: Towards a More Responsive Philosophy for the 21 ${ }^{\text {st }}$ Century," in Suri, 5 (2016), 1.

(C) 2021 Aldrin Mathew L. Go

https://www.kritike.org/journal/issue 28/go june2021.pdf

ISSN 1908-7330

(cc) BY-NC-ND 


\section{NOSTALGIA AND PHILOSOPHY-CONSUMPTION}

philosophy by local academics - not a taxonomy of Filipino philosophy. Thus, the culture of philosophy-consumption is now clear. What is characterized as "Filipino philosophy" is the consumption of discourses through the explication and application of philosophical theories or systems. The taxonomy of Filipino philosophy reveals that, to "prove" the existence of Filipino philosophy, you simply have to refer published works. The fundamental difference between the periodizations of foreign philosophies and Filipino philosophy is that the former account for paradigm shifts while the latter refers to shifts in philosophy-consumption.

My analysis done in this paper is by no means exhaustive nor a categorical declaration that Filipino philosophy does not exist. The critique is only a preliminary one. But what I do assert categorically in this paper is that there is a fundamental problem with how we relate and engage in philosophy: nostalgia and philosophy-consumption. The radical antagonism or gap that constrains the development of Filipino philosophy cannot be resolved by merely subscribing to Alfredo Co's mystifying mantra for Filipino philosophy, that as long as "you are a Filipino philosophizing, then that philosophy of yours becomes Filipino." 44 It is not enough that we simply abandon questioning the "Filipino-ness" of our philosophizing. There is also the need to criticize the way "philosophizing" is done in the country. But before we can even begin answering the question "What is Filipino Philosophy?" we ought to ask: Why does the question of Filipino philosophy persist? What was wrong with how philosophy was done before and how should we do philosophy today?

College of Liberal Arts, De La Salle University, Philippines

\section{References}

Abulad, Romualdo, "Contemporary Filipino Philosophy," in Karunungan, 1 (1988), 1-13.

"Doing Philosophy in the Philippines: Towards a More Responsive Philosophy for the 21 ${ }^{\text {st }}$ Century," in Suri, 5 (2016), 1-20.

Batoon, Emmanuel, "Tracing Mercado's Anthropological Perspective (Second in Two Parts)," in Kritike, 8 (2014), 1-18.

Baudrillard, Jean, Fatal Strategies, Translated by Phil Beitchman and W. G. J. Niesluchowski (Los Angeles: Semiotext(e), 2008) For a Critique of the Political Economy of the Sign, trans. by Charles Levin (New York: Verso Books, 2019).

${ }^{44}$ Co, "Doing Philosophy in the Philippines," 62.

(c) 2021 Aldrin Mathew L. Go

https://www.kritike.org/journal/issue 28/go june2021.pdf

ISSN 1908-7330

(cc) BY-NC-ND 
Simulacra and Simulation, trans. by Sheila Faria Glaser (Michigan:

The University of Michigan Press, 1994).

Symbolic Exchange and Death, trans. by Iain Hamilton Grant (London: SAGE Publishing, 1993).

Camus, Albert, The Myth of Sisyphus and Other Essays, trans. by Justin O'Brien (New York Vintage International, 1983).

The Rebel, trans. by Anthony Bower (New York: Vintage International, 1984).

Cariño, Jovito V., "Re-thinking Filipino Philosophy with Gilles Deleuze," in Mabini Review, 2 (2013), 57-72.

Co, Alfredo, "Doing Philosophy in the Philippines: Fifty Years Ago and Fifty Years from Now," in Across the Philosophical Silk Road Vol 6: Doing Philosophy in the Philippines and Other Essays (Manila: UST Publishing House, 2009), 49-62.

"In the Beginning... A Petit Personal Historical Narrative of the Beginning of Philosophy in the Philippines," in Across the Philosophical Silk Road Vol 6: Doing Philosophy in the Philippines and Other Essays (Manila: UST Publishing House, 2009), 28-45.

Deleuze, Gilles, Difference and Repetition, trans. by Paul Patton (Columbia: Columbia University Press, 1994).

Demeterio, F. P. A., III, "Assessing the Development Potentials of Some Twelve Discourses of Filipino Philosophy," in Philippiniana Sacra, 49 (2014), 189-230.

"A Critical Reflection on My Reading and Re-Reading of Emerita Quito's Thoughts on the Underdevelopment and Hope for the

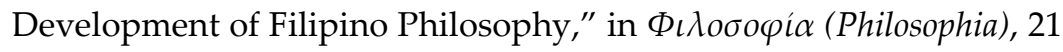
(2020), 169-186.

"Re-reading Emerita Quito's Thoughts Concerning the Underdevelopment of Filipino Philosophy," in Diwatao, 1 (2001), $<$ http://www.geocities.ws/philodept/diwatao/emerita_quito.html>. "Status of and Directions for 'Filipino Philosophy' in Zialcita, Timbreza, Quinto, Abulad, Mabaquiao, Gripaldo, and Co," in

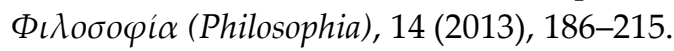

"Thought and Socio-Politics: An Account of the Late Twentieth Century of Filipino Philosophy," in F. P. A. Demeterio's Philosophy and Cultural Theory Page (2002), $<$ https://sites.google.com/site/feorillodemeterio/thoughtandsociopolitics>.

Hegel, G. W. F., Hegel's Phenomenology of Spirit, trans. by A. V. Miller (Oxford: Oxford University Press, 1977).

Joaquin, Nick, Culture and History (Manila: Anvil Publishing, 2004).

(c) 2021 Aldrin Mathew L. Go

https://www.kritike.org/journal/issue 28/go june2021.pdf

ISSN 1908-7330

(cc) BY-NC-ND 


\section{NOSTALGIA AND PHILOSOPHY-CONSUMPTION}

Kant, Immanuel, Critique of Pure Reason, trans. by Meiklejohn (London: Everyman's Library, 1993).

Mercado, Leonardo, Elements of Filipino Philosophy (Tacloban: Divine Word University Press, 1976). , Essays on Filipino Philosophy (Manila: Logos Publication, 2005). "Reflections on the Status of Filipino Philosophy," in Kritike, 10 (2016), 21-28.

Pada, Roland Theuas, "The Methodological Problems of Filipino Philosophy," in Kritike, 8 (2014), 22-44.

Quito, Emerita, The State of Philosophy in the Philippines (Manila: De La Salle University, 1983).

Žižek, Slavoj, Absolute Recoil: Towards A New Foundation of Dialectical Materialism (London: Verso Books, 2014). Less Than Nothing: Hegel and the Shadow of Dialectical Materialism (London: Verso Books, 2012).

Žižek, Slavoj and Glyn Daly, Conversations with Žižek (United Kingdom: Polity Press, 2004). 